Jurnal At-Tibyan: Jurnal Ilmu Alqur'an dan Tafsir Volume 6 No. 1, Juni 2021 (p. 81-95)

P ISSN 2442-594X | E ISSN 2579-5708

http://journal.iainlangsa.ac.id/index.php/tibyan

\title{
THE CONCEPT OF WIND AND DUST IN THE QUR'ĀN; A Study of Surah Ibrahim (14):18
}

\author{
Afrizal Nur \\ Universitas Islam Negeri Sultan Syarif Kasim Riau, Indonesia \\ afrizalnur12345@yahoo.com \\ Syafieh \\ Institut Agama Islam Negeri Langsa Aceh, Indonesia \\ syafieh@iainlangsa.ac.id \\ Raden Kurnia Kholiska \\ Universitas Islam Negeri Sunan Kalijaga Yogyakarta, Indonesia \\ nkhaliska@gmail.com \\ DOI 10.32505/at-tibyan.v6i1.2674 \\ \begin{tabular}{|l|l|l|}
\hline Submitted: 24-03-2021 & Revised: 07-06-2021 & Accepted: 12-06-2021 \\
\hline
\end{tabular}
}

\begin{abstract}
The article explains of one verses from the verse of amtal, namely Ibrahim verse 18 which discusses the interpretation of the tafsir scholars who explain the action committed by infidels and the ashes that are dust by strong winds when the wind blowns. The related example is the dust which blown by the wind because the dust turns out to be nothing and you will not be able to do anything if you are faced with strong winds in the high wind season, surely the dust will fly everywhere chaotically and will not be able to return to original place. Besides that, the dust that is contained in the Qur'ān is flying dust, where the flying dust has a negative impact and unbenefit to human health and the environment. This fact provides a very broad discourse enrichment, that the wind can occur if one day there is air pressure in the horizontal direction, there will be a movement of air mass transfer from a place with high air pressure to a place with low air pressure. Dust particles are known as small numbers of particles that are lifted up by the force of wind stress. The value of the wind stress force in this event is expressed by the fluid or threshold. This threshold depends not only on the properties of the fluid, but also on the gravity and cohesive forces between the particles which oppose the lift force of the fluid.
\end{abstract}

Keywords: interpretation, infidels, dust, wind

Copyright @ 2021. Owned by the Author, published by Jurnal At-Tibyan: Jurnal Ilmu Alqur'an dan Tafsir. Articles with open access. License: CC-BY

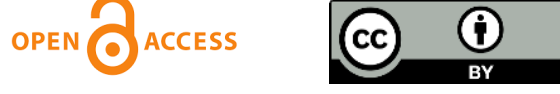




\begin{abstract}
Abstrak
Artikel ini menjelaskan satu dari ayat-ayat amsal yaitu surah Ibrahim ayat 18 yang membicarakan interpretasi ulama tafsir yang menjelaskan relasi antara amalan yang dilakukan orang kafir dengan abu yang ditiup angin dengan keras ketika angin kencang. Di permisalkan dengan debu yang tertiup angin karena debu ternyata tidak bernilai apa-apa dan tidak akan bisa berbuat apa-apa jika dihadapkan kepada angin yang kencang di musim angin kencang pula, tentunya debu tersebut akan berterbangan kemana-mana tidak karuan dan tidak akan bisa kembali kepada tempat semula. Selain itu debu yang terdapat didalam al-Qur'ān adalah debu yang berterbangan, dimana debu yang berterbangan memiliki dampak negatif dan ketidak bermanfaatan bagi kesehatan manusia dan lingkungan. Kenyataan ini memberikan sebuah pengayaan wacana sangat luas yaitu angin dapat terjadi jika suatu saat terjadi tekanan udara pada arah mendatar, maka akan terjadi gerakan perpindahan massa udara dari tempat yang tekanan udara yang tinggi ke tempat yang tekanan udara nya rendah. Partikel debu dikenal sebagai jumlah kecil partikel yang terangkat oleh gaya tegangan angin. Nilai gaya tegangan angin pada kejadian ini dinyatakan oleh fluida atau ambang batas. Ambang batas ini tidak hanya bergantung pada sifat-sifat fluida, tetapi juga bergantung pada gravitasi dan gaya kohesi antar-partikel yang berlawanan dengan gaya angkat fluida.
\end{abstract}

Kata kunci : Tafsir, kafir, Debu, Angin

\title{
Introduction
}

Islam is a perfect religion with the Qur'ān and Sunnah as the source of every aspect. From these sources, it will produce laws and regulations that will bring many benefits in regulating human life and become human beings who have faith, morals, and have a social life based on the Qur'ān and Sunnah.

The Qur'ān gives an indication of the laws of nature and the phenomena in this life with a very deep explanation and with a very convincing representation. They make it impossible to conflict with the attainment of human reason in its various phases. because we know that scientific discoveries are divided into two parts. The first one that is an argument and the reason that approaches the axiom, while the second part is still in the discussion phase (provisional assumptions), everything that exists in Scientists today is the form of hypotheses supported by definite and convincing arguments. However, every indication put forward by the Qur'ān is always in accordance with the invention of scientists.1

The relationship between Science and Religion in recent years is still an interesting issue to be studied. The long history of science and religion has given a complex relationships, such as harmony and disharmony. However, the issue of the relationship between religion and science is not always filled with contradictions and inconsistencies. Some societies are trying to find a relationship between the two, and

\footnotetext{
${ }^{1}$ Afrizal Nur and Muhamad Yasir, "The Interpretation of Verses 39 of An-Nur in the Perspective of Tafsir and Science," in Advances in Social Science, Education and Humanities Research (ASSEHR), vol. 137, 2017, 324-32, https://doi.org/10.2991/icqhs-17.2018.49.
} 
some of them think that religion and science could never be reconciled and have different identities, also their respective separate areas in terms of formal-material objects (ontology), research methods. (epistemology), and the function (axiology). ${ }^{2}$

According to Al-Attas, science is one unit, but can be categorized into two based on their nature and purpose. The first type of knowledge is the introduction which discuss how to obtain this knowledge based on revelation, inspiration and getting acquainted, disclosure (kasyf), and direct witnessing (musyahadah). The second type of science is obtained through the human mind and heart (qalb), experience and direct observation. The science of recognition, although at the initial level depends on science, it does not require evidence to validate it because it refers to an inner understanding of the nat ure of the spirit. Science according to Al-Attas is Ta'wil to the universe. $^{3}$

Several researchers have been carried out various studies on the relevance of the Qur'ān and science such as the creation of humans, ${ }^{4}$ the creation of the heavens and the earth, ${ }^{5}$ about the circulation of the sun and moon, ${ }^{6}$ meteors, ${ }^{7}$ cloud associations and rain, ${ }^{8}$ the phenomenon of lightning and thunder, ${ }^{9}$ the wonders of the sea ${ }^{10}$ and the gravity of the earth. ${ }^{11}$ The verses that talk about these natural phenomena are often closed with suggestions and invitations to think, reflect and do other logical activities.

As for the study of the relationship between Q. 14: 18 and science, it aims to enrich the study of the relevance of the Qur'ān and previous science. By using the theory of amtal in the Qur'ān, this article will interpret the parable mentioned in the Qur'ān about the actions of unbelievers before Allah SWT.

By using the interpretative hermeneutics coalition, the author sees Q. 14: 18 has a relationship with science, because in this verse not only talks about the uselessness of the deeds of unbelievers before Allah SWT, but contains scientific theories about wind and dust in human life.

\footnotetext{
${ }^{2}$ Damanhuri, "Relasi Sins Dan Agama Studi Pemikiran Ian G. Barbour," Refleksi: Jurnal Filsafat Dan Pemikiran Islam 15, no. 1 (2015): 30-44.

${ }^{3}$ Dinar Dewi Kania, “Pemikiran Epistemologi Al-Attas," Islamia 11, no. 2 (2017): 16-28.

${ }^{4}$ Eka Kurniawati and Nurhasanah Bakhtiar, "Manusia Menurut Konsep Al-Quran Dan Sains," Journal of Natural Science and Integration 1, no. 1 (2018): 78-94, https://doi.org/10.24014/jnsi.v1i1.5198.

${ }^{5}$ Gusti Afifah, Syahrial Ayub, and Hairunnisa Sahidu, "Konsep Alam Semesta Dalam Perspektif AlQuran Dan Sains," Jurnal GeoScienceEdu 1, no. 1 (2020): 5-10.

${ }^{6}$ Anisa Nur Afida and Mukarramah Mustari, "Matahari Dalam Perspektif Sains Dan Al- Qur' an," Indonesian Journal of Science and Mathematics Education 02, no. 1 (2019): 27-35.

${ }^{7}$ Muhammad Al Imron, Sodikin, and Romlah, "Meteors In The Perspective Of The Al-Qur'ān And Science," Indonesian Journal of Science and Mathematics Education 02, no. 3 (2019): 388-98.

${ }^{8}$ Rahendra Maya, "Fenomena Awan Cumulonimbus Dalam Al-Qur'ān," Jurnal Ilmu Al-Qur'ān Dan Tafsir 2, no. 2 (2015): 199-220.

${ }^{9}$ Nisaul Jannah and Muhammad Alfatih Suryadilaga, "Manfaat Air Bagi Tumbuhan: Perspektif AlQur'ān Dan Sains," AL QUDS: Jurnal Studi Alquran Dan Hadis 4, no. 2 (2020): 427-66, https://doi.org/10.29240/alquds.v4i2.1638.

${ }^{10}$ Sawal Sawaluddin Sawaluddinsiregar, “Air Dalam Perspektif Al-Qur'ān Dan Sains," Jurnal Tarbiyah: Jurnal Ilmiah Kependidikan 7, no. 2 (2018): 109-22, https://doi.org/10.18592/ tarbiyah.v7i2.2112.

${ }^{11}$ Mukhotob Hamzah and Badriyatul Muniroh, "Konsep Gaya Tarik (Gravitasi) Dalam Perspektif AlQur'ān Dan Sains (Kajian Surat Al-Hajj Ayat 65," SPEKTRA : Jurnal Kajian Pendidikan Sains 2, no. 2 (2016): 100-132, https://doi.org/10.32699/spektra.v2i2.13.
} 


\section{Ams̄älTheory in the Qur'ān}

Ams் $\bar{a} l$ in the Qur'ān as according to Abd. Ar Rahman Hasan al-Maidani is the mention of one or more examples to describe a variety of things, either in the form of acts or decrees of Allah by paying attention to the existing elements of equality. ${ }^{12} \mathrm{Ibn}$ al-Qayyim said that the mas்āl in the al-Qur'ān is to embellish something in the law, and to bring closer something abstract in a concrete form, or something concrete with also concrete. while Mushtafa Al-Maraghi defines the word masia 1 as similar or the same. Al Jazairi is referred to as that asks for views or seeing. ${ }^{13}$ So it is only natural that Manna 'Khalil al-Qaththan argues that the masiāl Qur'ān cannot be interpreted with the etymological meaning of as-syabih and an-nazir. It is also incorrect to interpret the meaning in the linguistic book used by the composers of the masial, because the masia $l$ al-Qur'ān is not the words used to equate something with the contents of the words. Nor can it be interpreted as meaning masia 1 according to the Bayan ulama, because among the matsal al-Qur'ān, some of them have no meanings and their function is not very popular. Here also the difference between masia 1 and tasybih, that the masial is not limited to equating something else, but a profound influence on the soul. Al-Jurjani explained the distinction between tasybih and masīal. Tasybih is general, while tamtsil is specific, every tamsisil is tasybih, but every tasybih is not necessarily tamsil. ${ }^{14}$

Al Suyuthiy defines amía $\bar{l}$ as describing meaning with a concrete image because it is more impressive in the heart, like equating the vague with the Visible, the gabib with the present. ${ }^{15}$ Meanwhile, Abu Sulaiman in commenting on the various definitions put forward by the amis $\bar{l} l$ expert said that the mas $\bar{a} l$ is to equate the state of something with the state of something else, the expression, can be isti'arah, sharil tasybih, or short verses with deep meaning (i ' jaz). Even so, it must be understood that not every mas $\bar{a} l$ must contain one of the three criteria stated above, because in its development it was found that there were verses from the Qur'ān because of a condition that society turned into a mas $\bar{a} l$. On the other hand, not every word / sentence that begins with the word maśāl immediately becomes masia 1 . Based on the description above, it can be understood that the amtal al-Qur'ān appears in a short, dense, alluring and full of meaning, because it is the same as the proverb in Indonesian. ${ }^{16}$ As for the various ams $\bar{a} l$ in the Qur'ān, the scholars have different opinions. Among them, al Suyuthi divides amtsal into two parts, namely amisāl al musyarrahāh and amsंāl al kaminah. Meanwhile, according to Manna 'al Qaththan and Muhammad Bakar Ismail divides amsīal into three types, namely al Musyarrahāh or al Qiyāsiah, al Kaminah and al Mursalah. ${ }^{17}$

\footnotetext{
${ }^{12}$ Mahbub Nuryadien, "Metode Amtsal; Metode Al-Quran Membangun Karakter," Jurnal At Tarbawi Al Haditsah 1, no. 2 (2013): 1-26, file:///C:/Users/HP/Downloads/1227-3142-1-PB (1).pdf.

${ }^{13}$ Ahmad Haromaini, "Studi Perumpamaan Al-Qur'ān," Islamika: Jurnal Agama. Pendidikan Dan Sosial Budaya 13, no. 1 (2019): 24-45, https://doi.org/10.33592/islamika.v13i1.152.

${ }^{14}$ M. Fatih, "Aspek-Aspek Pedagogis Dalam Amtsal Al- Qur'ān (Kajian Metodologis, Motivasi, Berfikir Kritis Dalam Pembelajaran Islam Integratif) M. Fatih," Ta'dibia: Jurnal Ilmiah Pendidikan Agama Islam 6, no. 2 (2016): 1-16

15 Tabrani Tabrani and Tabrani Muluk, "Metode Amtsal Dalam Pembelajaran Menurut Perspektif Al-Quran," Al-Fikra: Jurnal Ilmiah Keislaman 18, no. 1 (2019): 52-63, https://doi.org/10.24014/ af.v18i1.7712

${ }^{16}$ Haromaini, "Studi Perumpamaan Al-Qur’ān.

${ }^{17}$ Tabrani and Muluk, "Metode Amtsal Dalam Pembelajaran Menurut Perspektif Al-Quran."
} 


\section{Interpreting the Verse 18 of the Surah Ibrahim}

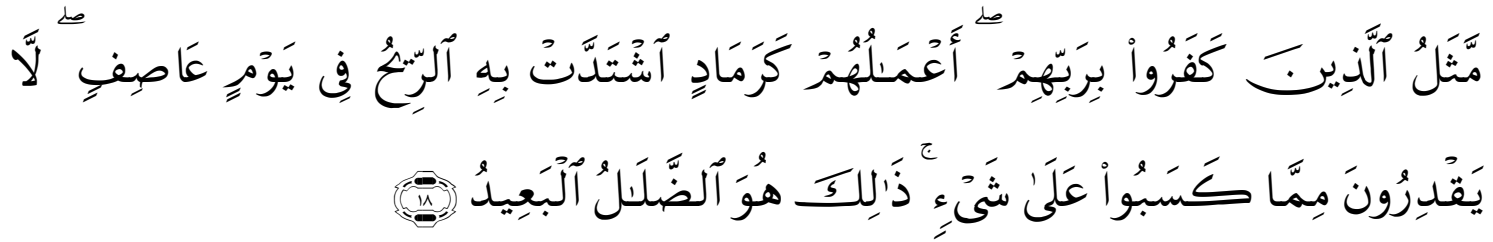

Translation: "Those who disbelieve in their Lord, their practices are like ashes which the wind blows violently on a windy day. they cannot take the slightest benefit from what they have tried (in the world). That is the far error". (QS. Ibrahim [14]:18)

The Munāsabah aspect of this verse is related to the previous verse, verse 13 through verse 17 which tells about the torments and threats that God inflicted on the previous people as a result of disbelief, besides their great losses due to the reward of their deeds removed.

According to Ibn Katsir's interpretation: this is a parable given by Allah to unbelievers who worshiped other parties besides Allah, denied His messengers, and established his charity on an invalid foundation. then the charity will be destroyed and destroyed when they really need it. So Allah said: the deeds of those who disbelieve in their God, namely the parable of their deeds on the Day of Judgment when they ask for their reward from Allah because they suspect that they have done something, then they do not find any reward and get no results except like ashes that a person gets when exposed to very strong winds "in high winds". they cannot take the slightest benefit from their charity, except as they are able to collect the ash in the high winds. ${ }^{18}$

This verse goes to the type of verse amtal, as we know Amía $l$ is like a situation with other conditions, for the same purpose, namely, to resemble something with the original. For example: "rubba ramiyah min gairi raminn". That is how much disaster caused by archer mistakes. The first person to say it like this is Hakam bin Yaghuts alNaqri, making the parable of people wrong with disaster even though sometimes it is true. ${ }^{19}$

The above verse is a type of ams $\bar{a} l$ musyarrahah that is explained by recite "masiāl" or something that shows tasybih (likeness) amsīal is often found in The Qur'ān as the above verse. Al-Zarkasiy briefly mentions the role of amsiāl of The Qur'ān, namely: warning, learning, motivation to do something, distancing yourself from something as a reflection of comparison, stabilizing something that is in the mind through a concrete picture, explaining the level of merit, praise and reproach, reward and retaliation, flatter and humiliate something. ${ }^{20}$

The scholars' commentators do not clearly mention the purpose of the amsia 1 of The Qur'ān. However, if we look closely at various benefits and verses of amsis $\bar{l}$ of The

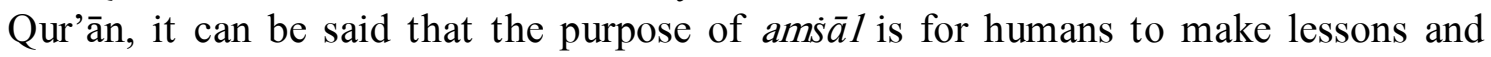
contemplations in the sense of good examples being used as examples while bad

\footnotetext{
${ }^{18}$ Fathurrohmah Aviciena, "Tafsir Surat Ibrahim Ayat 18, Surat Al-Baqarah Ayat 68, Dan Surat Yusuf Ayat 41 (Kajian Tentang Metode AmśÂl Dalam Pembelajaran Agama Islam)" (UIN Syarif Hidayatullah, 2015)

${ }^{19}$ Manna' Khalil al-Qattan, Mabāhis fì 'Uhüm al-Qur'ān, (Kairo: Maktabah Wahbah, 2000), 282

${ }^{20}$ Bahruddin Muhammad bin Abdillah al-Zarkasyi, Al-Burhān fì 'Uhūm Al-Qur'ān. Cet. III, (Bairut: Dar al-Ma'rifah li at-Thiba'ah, 1988), 131
} 
parables are avoided whenever possible. ${ }^{21}$ From the arguments of The Qur'ān and Hadith above it is clear that the purpose of amis $\bar{l} l$ of The Qur'ān is as an example and material for reflection so that humans are guided to the right path to achieve happiness in the life of the world and the hereafter.

The verse that has the same theme with verse 18 of the Surah Ibrahim is verse 23 of the Surah al-Furqan:

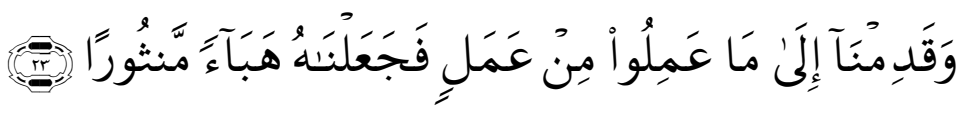

Translation: "And we face all the deeds that they do, then we make that charity (like) flying dust". (QS. Al-Furqan [25] : 23)

The idolaters in the life of this world do so many charities that are outwardly considered good according to them that charity will have a positive impact on the world, as well as the benefits will be felt in Judgment Day as in the world. but that was denied by Allah with verse 23 of the Surah al-Furqan. This verse is also a parable of the end of the "good" deeds of the unbelievers who do not believe in Allah and those who are strung in their deeds. their deeds will be in vain because they do not believe in Allah. Faith was made by God as a condition for accepting one's deeds. ${ }^{22}$

According to the As-Shobuniy's interpretation, the parables of the disbelievers they do in the world, for example, the desire to get a reply from the sodaqah they give and for the purpose of friendship they carry out and others are like dust blown by the wind, then God made the practice of the disbelievers is like: "flying dust" in the very strong wind season. this verse is a parable of the practices of unbelievers who themselves destroyed it or wiped it out as dust lifted by strong winds in the wind season, the result of their polytheism to God. And they (the unbelievers) are also not able to produce merit from the good deeds they have done as human helplessness also prevents it from being blown away by dust by strong winds. and this is a great regret and loss (As-Shobuniy : 94). Mus'ab bin Sa'ad asked his father, Sa'd bin Abi Waqqash, about the people who had lost the most. his father answered: "they are Jews and Christians. The Jews denounced the Prophet Muhammad, the Christians denounced heaven and said that there was no food and drink in heaven (H.R Bukhari).

According to Buya Hamka, the beginning of verse 18: "Conclusively, although there are also those who work on good deeds that may be good, but because there is no basis, do not grow on the basis of trust in God, just because, arrogant, looking for names, tearing the chest, then when it arrives the stiff of the charity will be blown away, fallen down, because it lies only on the sand, not veined to the bottom, "they did not get anything from what they were trying to sell even the slightest", completely wasted all the energy that had been shed for this.

The end of verse 18: "That is a heresy that has gone so far" and has gone so far astray, how to call him home again? and how to pick him up? nothing but obedience and clear mind and bright and bright light of the Faith, in exchange for the darkness of the mind, for not trusting God or disobeying God. A deep warning from the origin of the Meccan polytheists to "sabab Nuzul" (because of the verse), but it remains a guideline for the next community because the religious spirit must be renewed and the

\footnotetext{
${ }^{21}$ Nashrudin Baidan, Wawasan Baru Ilmu Tafsir, (Yogyakarta: Pustaka Pelajar: 2005), 252-253

${ }^{22}$ M.Quraish Shihab, Tafsir Al-Mishbah, Volume 9 (Jakarta: Lentera Hati, 2009), 51
} 
faith of monotheism must be kept alive. For the most unfortunate are people who live with no right foundation base upright. ${ }^{23}$

According to Al-Razi in his words as the parable of the disbelievers and their Lord, according to His words, they are people who have strayed very far. Know that God has mentioned various kinds of their torments which have been explained in the above verse., He explained in this verse that their deeds are only worth nothing. They don't benefit from any of that. And what is seen is a very heavy loss because they are useless on the Day of Judgment except a painful punishment and every thing they practice in the world and all they get is futility. ${ }^{24}$ And so these are two very heavy losses.

As is well known, there is a similarity between this parable and an action. The parable of a hurricane that blew away the ashes and scattered its parts so that there was no remainder of the ashes, and was not known. Thus, in fact, their disbelief makes every deed they have done in vain and disappears so that none of the deeds that are in them are known nor a trace.

According to Al-Maraghi from the general meaning After Allah mentions in His word what the unbelievers will face on this difficult day from all kinds of torments that Allah explained above is explained here that what they have done in the world in terms of good deeds will not help them one bit and not a little. What was suppose at that time with the ashes that were blown by the wind on a windy day the conclusions were drawn from each side, They did not find anything from their deeds in it, then they indicated that that day would definitely come, because Allah created the sky and the earth is helpless and invisible and able to destroy them and produce another creation, thus by His power nothing can prevent Him. ${ }^{25}$

(The parable of the disbelievers with His Lord their deeds are like ashes, with which the wind strengthens during the storm). As the actions of unbelievers they used to do in this world and claim that they will be lucky on the day of reckoning (doomsday). Unlike the ashes that are carried by the wind and carried by the wind on a windy day, it is crushed without leaving a trace. As is known on the Day of Resurrection, no one will benefit from Allah's side and be saved from His torment because what they did was not because of Allah. Instead they associate Allah and worship idols. What is meant by that act is good deeds, such as almsgiving, friendship, obeying parents, feeding people who are starving, providing help and so on.

M. QuraishShihab explained: "The deeds of the disbelievers are like flying ash, and surely the ash will be very easily blown away by the wind, and don't expect any remaining ashes. The wind that blew happened on a windy day that blew away something, let alone ash in all directions. This is a result of the practice they do not have something solid based on faith ${ }^{26}$.

"They cannot benefit at all" is interpreted by "they will not see the effect or impact of the deeds that they do before them on the Day of Judgment"127

\footnotetext{
${ }^{23}$ Amroeni Drajat, Ulumul Qur'ān: Pengantar Ilmu-Ilmu Al-Qur'ān (Jakarta: Kencana, 2017), 52.

${ }^{24}$ FakhruddinArRazi, MafatihulGhaibJilid 3, (Beirut: Dar Ihya At Turos Al Arabiy, 1423), 81.

${ }^{25}$ Ahmad Mustafa Al Maraghi, Tafsir Al Maraghi. Juz XIII. Cet. III, (Berikut: Ihyau al Tarikh al Araby, 1974), h 141

${ }^{26}$ Shihab, Tafsir Al-Mishbah, op-cit Voleme 6, h 350

${ }^{27}$ Bahjaz Abdul Wahid al Syaikhali,, Balaghatul Qur'ān fì alI’Jaz, 2001, MaktabahDandis , jilid 5, 241
} 
This is a parable of the disbelievers' actions like ashes flying on a day with strong winds, so that it is impossible for the ash not to fly and remain in its position. This happens because their deeds are not solid. They do good deeds, but they do not believe in Allah and there is no sincerity to them. Here it can be understood that the actions of unbelievers are something abstract, which cannot yet be understood. Then likened to dust blown by the wind on a strong windy day, is a concrete or real thing that is more understandable. So, like the purpose of proverbs is to explain what is still abstract, namely the condition of the disbelievers' actions with something more concrete, that is, like ashes that are blown by the wind in the windy season. ${ }^{28}$ In this verse what is likened is vanity or uselessness. The message conveyed through amis $\bar{l} l$ is more touching, more stable in conveying advice or prohibitions and more powerful.

\section{Wind and Dust in Science Perspective}

Wind can occur if at some time there is air pressure in the horizontal direction, there will be a movement of air mass transfer from places of high air pressure to places of low air pressure. ${ }^{29}$ The direction of the wind is the direction in which the wind blowing or from where the wind currents come and are determined in degrees determined by clockwise rotation and starting from the north point of the earth in other words according to the compass point. Generally, the wind currents that blow from the north then the north wind. the speed of the flowing wind currents and expressed in knots or kilometers per / hour or meters per second. ${ }^{30}$

Dust particles are known as small numbers of particles that are lifted by the wind force. The value of the wind stress force in this event is expressed by the fluid or threshold. ${ }^{31}$ This threshold depends not only on the properties of the fluid, but also on the gravity and inter-particle cohesion forces that are opposite to the fluid lifting force. The sketch of the force balance on the surface of the particle against the wind stress is stated in. Fluid threshold clearly comes from the dynamics or the influence of the threshold which is the lowest wind stress on the particles that occur continuously. For the condition of the Earth and Mars, the influence of the threshold is smaller than the fluid threshold because the effect of changing the momentum of the particles is more efficient than the filling of the fluid.

\footnotetext{
${ }^{28}$ Aviciena, "Tafsir Surat Ibrahim Ayat 18, 44.

${ }^{29}$ Sudirman Sudirman and Hadi Santoso, "Pengaruh Pengarah Angin Dan Kecepatan Angin Pada Turbin Savonius Tiga Sudu Terhadap Energi Listrik Yang Dihasilkan," Teknika: Jurnal Sains Dan Teknologi 16, no. 2 (2020): 255-60, https://doi.org/10.36055/tjst.v16i2.9073.

${ }^{30}$ Yanghao Liu et al., "Solidifying Dust Suppressant Based on Modified Chitosan and Experimental Study on Its Dust Suppression Performance," Adsorption Science and Technology 36, no. 1-2 (2018): 640-54, https://doi.org/10.1177/0263617417713624.

${ }^{31}$ Jasper F. Kok et al., "The Physics of Wind-Blown Sand and Dust," Reports on Progress in Physics 75, no. 10 (2012), 5. https://doi.org/10.1088/0034-4885/75/10/106901.
} 


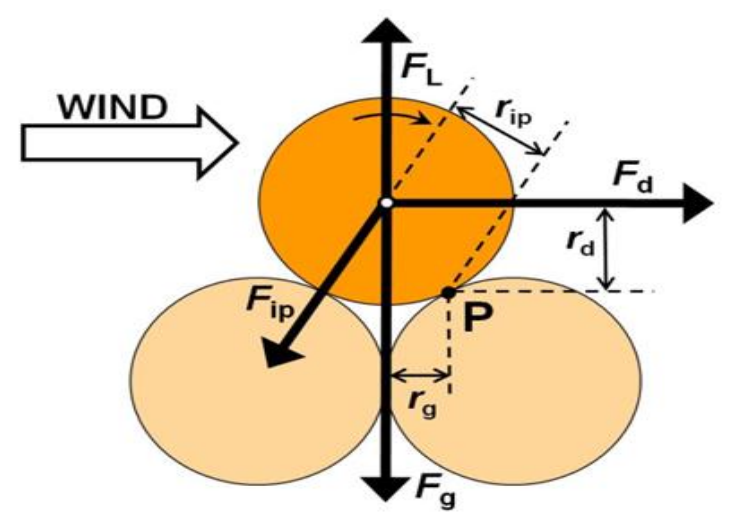

\begin{abstract}
Gambar 1. Skema gaya yang bekerja pada partikel debu dalam kondisi stasioner yang berada tetap diatas partikel lainnya. Gaya disimbolkan oleh tanda panah tebal, dan lengan momen gaya relatif terhadap sumbu putar P yang di indikasikan oleh tanda panah tipis. Ketika gaya angkat dan gaya tarik aerodinamika melebihi gaya gravitasi dan gaya antar partikel, maka partikel akan mengikuti gerak disekitar titik putar $\mathrm{P}$ dalam mengindikasikan arah.
\end{abstract}

The expression for fluid threshold can be derived from the balance of stationary surface forces of particles (figure 1). ${ }^{32}$ The surface of the particle will follow the motion of the turning point near the contact point of the supporting particle (in figure 1). This happens when the tensile $\left(F_{d}\right)$ and lift forces $\left(F_{l}\right)$ exceed the inter-particle forces $\left(F_{i p}\right)$ and the gravitational force $\left(F_{g}\right)$ when lifted is obtained:

$$
r_{d} F_{d} \approx r_{g}\left(F_{g}-F_{l}\right)+r_{i p} F_{i p}
$$

where $r_{d}, r_{g}, r_{i p}$ are the arm's moment of force in (figure 1), which is proportional to the particle diameter $D_{p}$. Effective gravitational force on fluids, including buoyancy, the equation becomes

$$
F_{g}=\frac{\pi}{6}\left(\rho_{p}-\rho_{a}\right) g D_{p}{ }^{3}
$$

Which $g$ is the acceleration due to gravity and $D_{p}$ is the same particle diameter as the irregularly shaped volume of dust particles. Particle density $\rho_{p}$ depends on the composition of the dust, but the value is for the earth's quartz (sand) dust. Next, the tensile forces generated by the fluid on the surface of the particles are given as follows:

$$
\boldsymbol{F}_{d}=\boldsymbol{k}_{d} \boldsymbol{\rho}_{a} \boldsymbol{D}_{p}{ }^{2} \boldsymbol{u}_{*}^{2}
$$

where $\rho_{a}$ the density of air, $k_{d}$ dimensionless coefficient with order, and stopping speed is the scale of the ratio of parameter to velocity gradient in boundary layer motion and is determined.

$$
\tau=\rho_{a} \boldsymbol{u}_{*}^{2}
$$

the fluid stop action $\tau$ is proportional to the horizontal momentum flux carried by the fluid with a combination of viscosity and turbulence downwards. The

\footnotetext{
${ }^{32}$ Kok et al., 13
} 
expression for the fluid threshold stops speed $\boldsymbol{U}_{* f t}$ at a dust particle is obtained by combining equations (1) - (2), which results:

$$
u_{* f t}=A_{f t} \sqrt{\frac{\rho_{p}-\rho_{a}}{\rho_{a}} g D_{p}}
$$

where the constant $A_{f t}$ is a function of the force between particles, the lift force, and the Reynold number. Regardless of the dependence and appropriateness of equation (5) for the free dust fluid threshold, for small inter-particle forces, is obtained $A_{f t} \approx 0,10$. Remember that the same expression for equation (5) can be used to describe the effect of the threshold $\boldsymbol{U}_{* i t}$, for the proportionality constant $A_{i t} \approx 0,082$. $^{33}$

Meanwhile, dust is a solid particle having a micron size (Tomary, 1975), whereas according to WHO (1999) dust is a solid particle with a carving between 1 pm to 100 $\mathrm{pm}$ that can become air pollutants depending on its origin, physical characteristics and ambient air conditions. As for the properties of dust are as follows ${ }^{34}$ :

1. Nature of deposition; the molecular weight of dust that is influenced by the earth's gravitational force causes dust to tend to be pulled down to the surface of the earth. However, if the weight is too low, the dust will rise and hover in the air because of the air flow around the dust. the lowest dust is likely to contain a greater proportion of particles than is present in the air.

2. Hygroscopic properties: on the surface of dust particles there is a thin layer of water caused by the phenomenon of absorption so that the dust is always wet. The hygroscopic properties of this property allow dust to bond with other chemicals. this property can be used to control dust by adding water to the dust so that the weight increases and settles on the ground or floor.

3. Clotting Properties: The layer of water present on the surface of the dust causes dust to easily bind to other chemicals and cause clotting. this phenomenon will be influenced by the surrounding air turbulence and the level of humidity that exceeds the saturation point which will increase the formation of clotting. because of these phenomena, there is a liquid that is concentrated in the dust and causes the particle size to be larger.

4. Electrical Properties: These properties cause dust to attract others that have different electrical charges. Contact that occurs between dust particles which have different dust charges will accelerate clumping and precipitation.

\footnotetext{
${ }^{33}$ Kok et al., 13

34 Ade Saptari, Analisis Pengendalian Debu pada Industri Mebel di Area Produksi Pre Cut PT X tahun 2011, Skripsi pada Program Keselematan dan Kesehatan Kerja, Fakultas Kesehatan Masyarakat, Universitas Indonesia, 2011, h. 9-10
} 
5. Optical properties: the optical properties possessed allow dust to reflect light known as the Tryndal Phenomenon. This phenomenon can be seen if there are rays that hit dust in a dark room.

\section{Relation between Flying Dust and Public Health}

Dust is a grain that can be produced by humans or in the wild which is produced by production or production processes in industrial activities. ${ }^{35}$ Dust exposure can make humans uncomfortable or disturbed, and can even cause health impacts.

The flying dust is a source of air pollution. The dust particles will remain in the air for a relatively long time while floating in the air and then enter the human body through inhalation. In addition to being harmful to health, it can also interfere with the visibility of the eye and can carry out various chemical reactions so that the composition of dust in the air becomes very complicated particles because it is a mixture of various materials with relatively different sizes and shapes. ${ }^{36}$

In the case of air pollution both inside and outside the building (Indoor and Outdoor Pollution), dust is often used as one of the indicators of pollution used to indicate the level of danger to both the environment and to occupational health and safety. The size of the dust is very influential on the occurrence of diseases in the respiratory tract.

According to the Indonesian Ministry of Health, the dangerous dust size ranges from 0.1 to 10 microns. Apart from having an impact on health, dust particles can also cause the following disorders:

1. Aesthetic and physical disturbances such as disturbed scenery and discoloration of buildings and pollution.

2. Damaging plant life that occurs as a result of the closure of plant pores so that it interferes with the course of photo synthesis.

3. Changing the global climate, regional and international.

4. Disturbing transportation / aviation which ultimately disrupts socio-economic activities in the community.

5. Disturbing human health such as irritation to the eyes, allergies, respiratory problems and lung cancer. The effect of dust on health depends largely on: solubity (soluble), chemical composition, dust concentration, and dust particle size. $^{37}$

Types of industries that produce dust and pollute the environment or the air are such as construction, agriculture and mining. In the manufacturing process, dust can also be generated from various activities such as crushing, grinding, abrasion and

\footnotetext{
${ }^{35}$ Nabilla Rachman Anjani, Mursid Raharjo, and Budiyono, "Hubungan Kadar Debu Terhirup Dengan Gangguan Fungsi Paru Pada Pekerja Industri Mebel Pt Marleny Jepara," Jurnal Kesehatan Masyarakat (e-Journal) 6, no. 6 (2018): 259-68.

${ }^{36}$ Anindya Mar and Sudarmaji, "Hubungan Karakteristik Pekerja Dan Kadar Debu Total Dengan Keluhan Pernapasan Pada Pekerja Industri Kayu X Di Kabupaten Lumajang,"Perspektif Jurnal Kesehatan Lingkungan 1, no. 1 (2015): 1-12.

${ }^{37}$ Anjani, Raharjo, and Budiyono, "Hubungan Kadar Debu Terhirup Dengan Gangguan Fungsi Paru Pada Pekerja Industri Mebel Pt Marleny Jepara."
} 
others. The amount of dust generated by industrial activities depends on the type of process and the materials used or processed. ${ }^{38}$

Fibrogenic dust such as crystalline silica (free crystalline silica - FCS) or asbestos is a type of dust that is very toxic and if it gets into the lungs it can damage the lungs and affect the function or work of the lungs.

Nuisance dust or inert dust can be defined as dust that contains less than $1 \%$ quartz (quartz). Due to its low silica content, nuisance dust has little effect on lung health and can be cured if inhaled. However, if the concentration of nuisance dust is very high in the air in the work area, it can reduce vision and can cause it to enter the eyes, ears and throat, causing discomfort and can also cause injury to the skin or mucous membrane either due to chemical or mechanical action. In terms of occupational health, dust is classified into three categories, namely: Respirable Dust, Inhalable Dust, and Total Dust.

Respirable dust is dust or particles that are small enough that can enter the nose to the upper respiratory system and enter the inner lungs. Particles that enter the inner lungs or inner respiratory system in general cannot be removed by the body's natural mechanisms (cilia and mucous) so as a result these particles will stay forever in the lungs. 39

The EPA describes inhalable dust as dust that can enter the body but is trapped or retained in the nose, throat, or upper respiratory system, the size of inhalable dust about 10 microns in diameter. Total dust is all airborne particles regardless of size and composition.

Excessive or prolonged exposure to harmful respirable dusts can cause a respiratory disease called pneumoconiosis. This disease is caused by the accumulation or accumulation of mineral dust in the lungs and damaging the lung tissue. Pneumoconiosis is the common name for a dust-caused lung disease. Some types of pneumoconiosis are:

1. Silicosis - Silicosis is a pneumoconiosis caused by quartz or silica dust. This lung condition is characterized by nodular fibrosis (scarring of the lung tissue), resulting in shortness of breath. Silicosis is a disease that is irreversible or incurable, even the advanced stages are progressive even though they are no longer exposed.

2. Black Lung - Black lung is a form of pneumoconiosis that is caused by a buildup of coal dust in the lungs which darkens the lung tissue or darkens it. This disease is also progressive. Although the name of this disease is widely known as black lung disease, the official name is coal workers pneumoconiosis (CWP).

\section{Conclusions}

Surah Ibrahim verse 18 which exemplifies the actions of unbelievers like dust flying in a strong wind. The scholars' tafsir argued that this was because of their disbelief to Allah. Even though they do good deeds, they do not believe in Allah, just

\footnotetext{
${ }^{38}$ Subarkah, Triyantoro, and Khomsatun, "Hubungan Paparan Debu Dan Masa Kerja Dengan Keluhan Pernafasan Pada Tenaga Kerja Cv. Jiyo'G Konveksi Desa Notog Kecamatan Patikraja Kabupaten Banyumas Tahun 2017.”

${ }^{39}$ Mar and Sudarmaji, "Hubungan Karakteristik Pekerja Dan Kadar Debu Total Dengan Keluhan Pernapasan Pada Pekerja Industri Kayu X Di Kabupaten Lumajang."
} 
because they are arrogant, looking for names, then it is like the coming of a strong wind. Charities that are exhaled and wasted. The deeds of unbelievers are futile, not getting the benefits that are only grievous losses and punishments. The parable of a hurricane that blows away the ashes and spreads its parts so that there is no remainder of the ashes and is not known. The actions referred to are good deeds, such as almsgiving, friendship, obeying parents, feeding people who are starving, providing help and so on. So it is clear that the purpose of amtsal is to explain what is still abstract, namely the state of the actions of an infidel with something more concrete, namely like ashes blown by the wind in a strong wind season.

Besides that, the dust that is contained in the Koran is flying dust, where the flying dust has a negative impact and is of no benefit to human health and the environment. This fact provides a very broad discourse enrichment, namely that the wind can occur if one day there is air pressure in the horizontal direction, there will be a movement of air mass transfer from a place with high air pressure to a place with low air pressure. The dust particles are known as the small number of particles that are lifted up by the force of the wind stress. The value of the wind stress force in this event is expressed by the fluid or threshold. This threshold depends not only on the properties of the fluid, but also on the gravity and cohesive forces between the particles which oppose the lift force of the fluid.

\section{BIBLIOGRAPHY}

Afida, Anisa Nur, and Mukarramah Mustari. "Matahari Dalam Perspektif Sains Dan A1- Qur' an." Indonesian Journal of Science and Mathematics Education 02, no. 1 (2019): 27-35.

Afifah, Gusti, Syahrial Ayub, and Hairunnisa Sahidu. "Konsep Alam Semesta Dalam Perspektif Al-Quran Dan Sains.” Jurnal GeoScienceEdu 1, no. 1 (2020): 5-10.

Anjani, Nabilla Rachman, Mursid Raharjo, and Budiyono. "Hubungan Kadar Debu Terhirup Dengan Gangguan Fungsi Paru Pada Pekerja Industri Mebel Pt Marleny Jepara." Jurnal Kesehatan Masyarakat (e-Journal) 6, no. 6 (2018): 259-68.

Aviciena, Fathurrohmah. "Tafsir Surat Ibrahim Ayat 18, Surat Al-Baqarah Ayat 68, Dan Surat Yusuf Ayat 41 (Kajian Tentang Metode Amś Âl Dalam Pembelajaran Agama Islam)." UIN Syarif Hidayatullah, 2015.

Al-Maraghi, Ahmad Musthafa. Tafsir Maraghi Juz 13. Mesir: Perpustakaan dan percetakan Mustafa Al-Babu Al-Halabi wa Auladihi, 1974.

Al-Qattan, Manna' Khalil. Mabāhis fi 'Uh̄̄m al-Qur'ān. Kairo: Maktabah Wahbah, 2000.

Al-Zarkasyi, Bahruddin Muhammad bin Abdillah. Al-Burhān fì 'Uhùm Al-Qur'ān. Cet. III. Bairut: Dar al-Ma'rifah li at-Thiba'ah, 1988.

Ar-Razi, Fakhruddin. Mafatihul Ghaib Jilid 3. Beirut: Dar Ihya At Turos Al Arabiy, $1423 \mathrm{H}$. 
Baidan, Nashruddin. Wawasan Baru Ilmu Tafsir. Yogyakarta: Pustaka Pelajar, 2005.

Damanhuri. "Relasi Sins Dan Agama Studi Pemikiran Ian G. Barbour." Refleksi: Jurnal Filsafat Dan Pemikiran Islam 15, no. 1 (2015): 30-44.

Drajat, Amroeni. Ulumul Qur'ān: Pengantar Ilmu-Ilmu Al-Qur'ān. Jakarta: Kencana, 2017.

Faizin. "Integrasi Agama Dan Sains Dalam Tafsir Ilmi Kementerian Agama RI." Jurnal Ushuluddin 25, no. 1 (2017): 19-33. https://doi.org/10.24014/jush.v25i1.2560.

Hamzah, Mukhotob, and Badriyatul Muniroh. "Konsep Gaya Tarik (Gravitasi) Dalam Perspektif Al-Qur'ān Dan Sains (Kajian Surat Al-Hajj Ayat 65." SPEKTRA: Jurnal Kajian Pendidikan Sains 2, no. 2 (2016): 100-132. https://doi.org/ 10.32699/spektra.v2i2.13.

Haromaini, Ahmad. "Studi Perumpamaan Al-Qur'ān." Islamika: Jurnal Agama. Pendidikan Dan Sosial Budaya 13, no. 1 (2019): 24-45. https://doi.org/10.33592/ islamika.v13i1.152.

Imron, Muhammad Al, Sodikin, and Romlah. "Meteors In The Perspective Of The AlQur'ān And Science." Indonesian Journal of Science and Mathematics Education 02, no. 3 (2019): 388-98.

Jannah, Nisaul, and Muhammad Alfatih Suryadilaga. "Manfaat Air Bagi Tumbuhan: Perspektif Al-Qur'ān Dan Sains." AL QUDS : Jurnal Studi Alquran Dan Hadis 4, no. 2 (2020): 427-66. https://doi.org/10.29240/alquds.v4i2.1638.

Kania, Dinar Dewi. "Pemikiran Epistemologi Al-Attas." Islamia 11, no. 2 (2017): 1628.

Kok, Jasper F., Eric J.R. Parteli, Timothy I. Michaels, and Diana Bou Karam. "The Physics of Wind-Blown Sand and Dust." Reports on Progress in Physics 75, no. 10 (2012). https://doi.org/10.1088/0034-4885/75/10/106901.

Kurniawati, Eka, and Nurhasanah Bakhtiar. "Manusia Menurut Konsep Al-Quran Dan Sains." Journal of Natural Science and Integration 1, no. 1 (2018): 78-94. https://doi.org/10.24014/jnsi.v1i1.5198.

Liu, Yanghao, Wen Nie, Hu Jin, He Ma, Yun Hua, Peng Cai, and Wenle Wei. "Solidifying Dust Suppressant Based on Modified Chitosan and Experimental Study on Its Dust Suppression Performance." Adsorption Science and Technology 36, no. 1-2 (2018): 640-54. https://doi.org/10.1177/0263617417713624.

Lune, H., and B. L. Berg. Qualitative Research Method for the Social Sciences. Edinburgh: Pearson Education Limited, 2017.

M. Fatih. “Aspek-Aspek Pedagogis Dalam Amtsal Al- Qur'ān (Kajian Metodologis, Motivasi, Berfikir Kritis Dalam Pembelajaran Islam Integratif) M. Fatih." Ta'dibia: Jurnal Ilmiah Pendidikan Agama Islam 6, no. 2 (2016): 1-16.

Mar, Anindya, and Sudarmaji. "Hubungan karakteristik pekerja dan kadar debu total dengan keluhan pernapasan pada pekerja industri kayu $\mathrm{x}$ di kabupaten lumajang." Perspektif Jurnal Kesehatan Lingkungan 1, no. 1 (2015): 1-12.

Maya, Rahendra. "Fenomena Awan Cumulonimbus Dalam Al-Qur'ān.” Jurnal Ilmu AlQur'ān Dan Tafsir 2, no. 2 (2015): 199-220.

Nur, Afrizal, and Muhamad Yasir. "The Interpretation of Verses 39 of An-Nur in the 
Perspective of Tafsir and Science." In Advances in Social Science, Education and Humanities Research (ASSEHR), 137:324-32, 2017. https://doi.org/10.2991/ icqhs-17.2018.49.

Nuryadien, Mahbub. "Metode Amtsal; Metode Al-Quran Membangun Karakter." Jurnal At Tarbawi Al Haditsah 1, no. 2 (2013): 1-26. file:///C:/Users/HP/ Downloads/1227-3142-1-PB (1).pdf.

Saptari, A D E. "Pada Industri Mebel Di Area Produksi Pre Cut Pt X Tahun 2011 Di Area Produksi Pre Cut Pt X Tahun 2011.” Program Keselamatan Dan Kesehatan Kerja. Universitas Indoensia, 2011.

Sawaluddinsiregar, Sawal Sawaluddin. "Air Dalam Perspektif Al-Qur'ān Dan Sains." Jurnal Tarbiyah: Jurnal Ilmiah Kependidikan 7, no. 2 (2018): 109-22. https://doi.org/10.18592/tarbiyah.v7i2.2112.

Subarkah, Mahfud, Budi Triyantoro, and Khomsatun Khomsatun. "Hubungan Paparan Debu Dan Masa Kerja Dengan Keluhan Pernafasan Pada Tenaga Kerja Cv. Jiyo'G Konveksi Desa Notog Kecamatan Patikraja Kabupaten Banyumas Tahun 2017.” Buletin Keslingmas 37, no. 3 (2018): 270-82. https://doi.org/10.31983/ keslingmas.v37i3.3874.

Sudirman, Sudirman, and Hadi Santoso. "Pengaruh Pengarah Angin Dan Kecepatan Angin Pada Turbin Savonius Tiga Sudu Terhadap Energi Listrik Yang Dihasilkan." Teknika: Jurnal Sains Dan Teknologi 16, no. 2 (2020): 255-60. https://doi.org/10.36055/tjst.v16i2.9073.

Shihab, M.Quraish, Tafsir Al-Mishbah. Jakarta: Lentera Hati, 2009.

Tabrani, Tabrani, and Tabrani Muluk. "Metode Amtsal Dalam Pembelajaran Menurut Perspektif Al-Quran.” Al-Fikra : Jurnal Ilmiah Keislaman 18, no. 1 (2019): 52-63. https://doi.org/10.24014/af.v18i1.7712.

Tomany, James P. Air Pollution; The emissions, The Regulation, and The (1st ed). New York. American Elsevier Publishing Company Inc, 1975. 